\title{
AIB1 sequestration by androgen receptor inhibits estrogen-dependent cyclin D1 expression in breast cancer cells
}

Francesca De Amicis ${ }^{\dagger}$, Chiara Chiodo $^{\dagger}$, Catia Morelli, Ivan Casaburi, Stefania Marsico, Rosalinda Bruno, Diego Sisci ${ }^{*}$, Sebastiano Andò ${ }^{\dagger}$ and Marilena Lanzino ${ }^{*}$

\begin{abstract}
Background: Androgens, through their own receptor, play a protective role on breast tumor development and progression and counterbalance estrogen-dependent growth stimuli which are intimately linked to breast carcinogenesis.

Methods: Cell counting by trypan blu exclusion was used to study androgen effect on estrogen-dependent breast tumor growth. Quantitative Real Time RT-PCR, western blotting, transient transfection, protein immunoprecipitation and chromatin immunoprecipitation assays were carried out to investigate how androgen treatment and/or androgen receptor overexpression influences the functional interaction between the steroid receptor coactivator AIB1 and the estrogen- or androgen receptor which, in turn affects the estrogen-induced cyclin D1 gene expression in MCF-7 breast cancer cells. Data were analyzed by ANOVA.

Results: Here we demonstrated, in estrogen receptor a (ERa)-positive breast cancer cells, an androgen-dependent mechanism through which ligand-activated androgen receptor (AR) decreases estradiol-induced cyclin D1 protein, mRNA and gene promoter activity. These effects involve the competition between AR and ERa for the interaction with the steroid receptor coactivator AIB1, a limiting factor in the functional coupling of the ERa with the cyclin D1 promoter. Indeed, AIB1 overexpression is able to reverse the down-regulatory effects exerted by AR on ERamediated induction of cyclin D1 promoter activity. Co-immunoprecipitation studies indicated that the preferential interaction of AIB1 with ERa or AR depends on the intracellular expression levels of the two steroid receptors. In addition, ChIP analysis evidenced that androgen administration decreased $\mathrm{E}_{2}$-induced recruitment of AIB1 on the AP-1 site containing region of the cyclin D1 gene promoter.

Conclusions: Taken together all these data support the hypothesis that AIB1 sequestration by AR may be an effective mechanism to explain the reduction of estrogen-induced cyclin D1 gene activity. In estrogen-dependent breast cancer cell proliferation, these findings reinforce the possibility that targeting AR signalling may potentiate the effectiveness of anti-estrogen adjuvant therapies.
\end{abstract}

Keywords: Breast cancer, MCF-7, Androgen receptor, Estrogen receptor, Dihydrotestosterone, Estradiol, Coactivators, AlB1, SRC3, Cyclin D1

\footnotetext{
*Correspondence: diego.sisci@unical.it

Francesca De Amicis and Chiara Chiodo equally contributed to this work.

Department of Pharmacy, Health and Nutritional Sciences, University of

Calabria, CS, 87036 Arcavacata di Rende, Italy
}

(c) The Author(s). 2019 Open Access This article is distributed under the terms of the Creative Commons Attribution 4.0 International License (http://creativecommons.org/licenses/by/4.0/), which permits unrestricted use, distribution, and reproduction in any medium, provided you give appropriate credit to the original author(s) and the source, provide a link to the Creative Commons license, and indicate if changes were made. The Creative Commons Public Domain Dedication waiver (http://creativecommons.org/publicdomain/zero/1.0/) applies to the data made available in this article, unless otherwise stated. 


\section{Background}

The high frequency of androgen receptor (AR) expression in primary breast tumours $(70-90 \%)[1,2]$ suggests that androgens are important modulators of breast cancer cell proliferation [3]. Androgens have inhibitory effects on the proliferation of normal breast epithelial cells and play a protective role in the pathogenesis of breast cancer growth [4,5]. Indeed, several events involved in breast cancer genesis or progression have been shown to alter AR expression or function. In BRCA1-mutated tumours, loss of AR expression, and thus loss of AR signalling, supports neoplastic transformation of mammary epithelial cells [6]. AR signalling influence on breast cancer depends on the contest of the different subtype of disease [3] as indicated by a number of studies showing that the expression of AR is a favourable determinant of survival in estrogen receptor alpha $(E R \alpha)$-positive, but not ER $\alpha$-negative breast cancer patients [7-9]. These observations have been recently confirmed. A wide study, conducted on 4147 pre- and postmenopausal women with invasive breast cancer found that, in the 7 years following diagnosis, AR expression was associated with improved prognosis in $\mathrm{ER} \alpha$-positive tumors and worse prognosis in $\mathrm{ER} \alpha$ negative ones [10].

Similarly, in luminal ER $\alpha$-positive breast cancer cell lines, AR exerts an anti-proliferative effect [11-16] while in MDA-MB-453, a model of ER $\alpha$-negative apocrine disease, activated AR can induce cancer growth $[17,18]$. It has been proposed that androgens are able to counterbalance positive growth stimuli in the breast since they antagonize the estrogen-induced proliferative effects which are intimately linked to breast carcinogenesis [3]. In vivo studies in rhesus monkey evidenced that blocking the action of endogenous androgens results in a significant increase in mammary epithelial cell proliferation. Conversely, in ovariectomized animals, low doses of testosterone completely inhibit estrogeninduced mammary cell proliferation $[19,20]$.

In estrogen-receptor positive breast cancer cell lines the non-aromatisable androgen 5- $\alpha$-dihydrotestosterone (DHT) inhibits both basal and estradiol-induced proliferation [7, 13]. Co-administration of testosterone suppresses the estradiol $\left(\mathrm{E}_{2}\right)$-mediated induction of $\mathrm{MYC}$ [21] and over-expression of the AR in MCF-7 cells markedly decreased estrogen receptor $\alpha(E R \alpha)$ transcriptional activity [7, 14, 22] consistent with the notion that androgens inhibit estrogen-dependent signalling pathways.

Estrogens particularly exert their proliferative effects by induction of the G1 progression and G1/S transition through a mechanism involving the transcriptional control of cell cycle regulatory genes such as CCND1, encoding cyclin D1 $[23,24]$.
Overexpression of cyclin D1 is believed to endow mammary epithelial cells with a proliferative advantage by virtue of its contribution to $\mathrm{pRB}$ inactivation. Conversely, mice deficient in cyclin D1 activity show an autophagy-like process [25].

The correlation between CCND1 expression levels and cellular proliferation in breast cancer cells has been also confirmed by $C C N D 1$ silencing experiments, indicating cyclin D1 as a potential therapeutic target for breast cancer [26, 27].

We previously reported that CCND1 represents a target gene of DHT-activated AR in MCF-7 breast cancer cells, evidencing the existence of a functional Androgen Response Element within the CCND1 promoter, which mediates the DHT/AR inhibitory effects on basal breast cancer cell proliferation [13].

Since cyclin D1 has been shown to mediate $\mathrm{E}_{2}$-induced progression of MCF-7 from G1 into S phase, here we examined the possibility of the existence of an additional mechanism by which androgens, through their own receptor, may inhibit $\mathrm{E}_{2}$-induced cyclin D1 expression thus modulating estrogen-dependent breast cancer cell proliferation. In this report we demonstrate that in MCF-7 and in MCF-7 over-expressing the AR, DHT treatment decreases the $E_{2}$-dependent expression of cyclin D1 protein as well as the transcriptional activity of the cyclin D1 gene promoter. We propose that the competition for the steroid receptor coactivator AIB1, that is important in the functional coupling of the ER $\alpha$ with the cyclin D1 promoter [28], may represent a possible mechanism through which AR can modulate ER $\alpha$-mediated signalling pathway on cyclin D1 gene leading to the inhibition of breast cancer cell proliferation.

\section{Methods}

\section{Reagents and antibodies}

Dihydrotestosterone (DHT), hydroxyflutamide (OH-Fl) and estradiol $\left(\mathrm{E}_{2}\right)$ were from Sigma Aldrich; antibodies against AR (441), cyclin D1 (M-20), ER $\alpha$ (F-10), GAPDH (FL-335), Actin (AC-15) were from Santa Cruz Biotechnology.

\section{Cell cultures}

The human breast cancer MCF-7 (ATCC-HB-22) or human cervical cancer HeLa (ATCC- CRM-CCL-2) cell lines were acquired from ATCC (LCG Standards, UK). Cells were stored according to supplier's instructions, and used within 6 months after frozen aliquots resuscitations. Cells were authenticated by short tandem repeat analysis (GenePrint ${ }^{\odot} 10$ System, Promega) at our Sequencing Core Facility. Mycoplasma negativity was tested monthly (MycoAlert, Lonza). Before each experiment, cells were synchronized in phenol red-free serum free media (PRF-SFM) for $24 \mathrm{~h}$. All the experiments were 
performed in PRF-media containing 2.5\% charcoaltreated (steroids depleted) Fetal Bovine Serum (PRF$\mathrm{CT}$ ). Cells were treated with $10^{-8} \mathrm{M} \mathrm{E} 2$, and/or $10^{-7} \mathrm{M}$ DHT, and/or $10^{-6} \mathrm{M}$ OHFl.

\section{Cell proliferation assays}

Cells were seeded on six-well plates $\left(2 \times 10^{5}\right.$ cells/well $)$ in $2.5 \%$ PRF-CT. After $24 \mathrm{~h}$, cells were exposed for 3 days to $10^{-7} \mathrm{M} \mathrm{DHT}$ and/or $10^{-7} \mathrm{M} \mathrm{E}_{2}$ and/or $10^{-6} \mathrm{M} \mathrm{OHFl,}$ or left untreated (-) and then harvested by trypsin. Drug effects on cell proliferation were measured by counting cells using a Burker's chamber; cell viability was determined by Trypan blue dye exclusion test as previously described [12].

\section{Plasmids, transfections and luciferase reporter assays}

The following plasmids were used: Cyclin D1 promoter construct D1 $\Delta$-2966pXP2-Luc (a gift from Dr. A. Weisz, Università degli Studi di Salerno, Italy); wild-type AIB1 expression vector (a gift from Dr. B. O'Malley, Baylor College of Medicine, Houston TX USA); pcDNA3-AR (AR), encoding full-length androgen receptor, (a gift from Dr. M.J. McPhaul, UT-Southwestern Medical Center at Dallas TX, USA), the wild-type human ER $\alpha$ (HEGO) (a gift from Dr. P. Chambon, Université de Strasbourg, France).

Cells were transfected using Fugene 6 reagent (Roche Diagnostics) according to manufacturer's instructions. Renilla reniformis luciferase expression vector pRL-Tk (Promega) was used to assess transfection efficiency. Luciferase activity was measured with the Dual Luciferase kit (Promega).

Total RNA extraction, reverse transcription polymerase PCR and real-time RT-PCR assay

Total RNA was extracted from MCF-7 cells using TRIzol reagent and cDNA was synthesized by reverse transcription-polymerase chain reaction (PCR) method using a RETROscript kit. The expression of selected genes was quantified by real-time PCR using iCycler iQ Detection System (Bio-Rad, Hercules, CA) as previously described [29]. Five microliters of diluted (1:3) cDNA was analyzed using SYBR Green Universal PCR Master Mix, following the manufacturer's recommendations. The primers (Invitrogen) for Cylin D1 gene were: forward: 5' CCGTCCATGCGGAAGATC-3'; reverse: 5'-AAACGT GGGTCTGGGCAA-3'. Each sample was normalized on the basis of its $18 \mathrm{~S}$ ribosomal RNA content. The $18 \mathrm{~S}$ quantification was performed using a TaqMan Ribosomal RNA Reagent kit (Applied Biosystems) following the method provided in the TaqMan Ribosomal RNA Control Reagent kit. The relative gene expression levels were normalized to a calibrator that was chosen to be the basal, untreated sample. Final results were expressed as n-fold differences in gene expression relative to $18 \mathrm{~S}$ ribosomal RNA and calibrator, calculated following the $\Delta \Delta$ Threshold cycle $(\mathrm{Ct})$ method, as published previously. Assays were performed in triplicate.

\section{Immunoprecipitation and WB}

Total cell proteins were obtained from $70 \%$ confluent cell cultures. Immunoprecipitation (IP) and Western blotting (WB) were performed as previously described [22, 30]. The images were acquired by using an Epson Perfection scanner (Epson, Japan) using Photoshop software (Adobe). The optical densities of the spots were analyzed by using ImageJ software (NIH; http://rsb.info.nih.gov/IJ).

\section{Chromatin Immunoprecipitation (ChIP) assay and real time ChIP}

ChIP assay was performed as previously described [29]. Immuno-cleared chromatin was precipitated with antiAIB1 or anti-ER $\alpha$ antibody. Immunoprecipitated DNA was analyzed in triplicates by real-time PCR by using $5 \mu \mathrm{l}$ of the diluted (1:3) template DNA. The following primers (Invitrogen) spanning the AP-1 site of the Cyclin D1 promoter were used: forward 5' - CTTCGGTGGTCTTGTCCCA- 3' and reverse 5 ' - CTTCCCGTGCCGGCAATTTA- 3 '.

Real-time PCR data were normalized with respect to unprocessed lysates (input DNA). Inputs DNA quantification was performed by using $5 \mu \mathrm{l}$ of the diluted $(1 / 50)$ template DNA. The relative antibody bound fractions were normalized to a calibrator that was chosen to be the basal, untreated sample. Final results were expressed as percent to the relative inputs as previously described.

\section{RNA silencing}

AIB1 silencing experiments were performed using Stealth $^{\text {tw }}$ Select RNAi (Invitrogen) annealed duplexes. Non-specific (NS) siRNA was used as a control for nonsequence-specific effects. Cells were transfected with 100 pmol of siRNA AIB1 or NS siRNA, using Lipofectamine 2000 (Invitrogen Life Technologies), following manufacturer's instructions.

\section{Statistical analysis}

Statistical analysis was performed using ANOVA followed by Newman-Keuls' testing to determine differences in means. All data are reported as the mean \pm SD of three different experiments, each performed in triplicates. ${ }^{*} p \leq 0.05$ vs control.

\section{Results}

Inhibition of estrogen-dependent proliferation by androgen receptor over-expression

We previously demonstrated that MCF-7 cells are androgen-responsive and that DHT treatment induces a 
transient increase in AR protein levels [22] similar to that seen in other cell types [31, 32].

Thus, we investigated the role of DHT-dependent signalling on the $\mathrm{E}_{2}$-induced proliferation of the ER $\alpha$ positive MCF-7 cells. Consistent with previous reports $[13,14]$, prolonged DHT administration resulted in a significant reduction of basal as well as $\mathrm{E}_{2}$-dependent MCF-7 cell proliferation (Fig. 1). To better investigate the role of androgen receptor, MCF-7 cells were transiently transfected with the pcDNA3-AR expressing the full length AR (MCF-7 cells/AR). The ectopic overexpression of AR "per se" reduced $\mathrm{E}_{2}$-dependent cell proliferation and further potentiates the inhibitory effects determined by DHT administration. Addition of the androgen antagonist hydroxyflutamide (OHFl) effectively reversed the inhibition of $E_{2}$-induced cell growth exerted by DHT, suggesting that the effect was mediated by AR.

\section{Inhibition of $\mathrm{E}_{2}$-induced cyclin D1 gene expression and} promoter activity by androgen receptor over-expression

Since a key rate-limiting event in mitogenic estradiol signalling leading to S-phase entry is the induction of cyclin D1 [33] we investigated whether AR activation and/or its over-expression might modulate cyclin D1 expression.

To this aim, MCF-7 cells were transiently transfected with an empty vector or with a full length AR expression plasmid and left untreated or treated with $E_{2}$ and/or DHT for $48 \mathrm{~h}$. A significant reduction in the $\mathrm{E}_{2}$-induced cyclin D1 protein expression levels was observed following DHT co-treatment in MCF-7 cells. Interestingly, AR overexpression per se determined a decrease of cyclin D1 protein content in response to $E_{2}$ stimulation, which was further reduced following DHT coadministration (Fig. 2a). A similar regulatory pattern was observed in terms of mRNA expression levels (Fig. 2b).

Next, we examined the possibility that AR activation by its own ligand and/or AR over-expression might negatively modulate the $\mathrm{E}_{2} / \mathrm{ER} \alpha$-induced cyclin $D 1$ promoter transcriptional activity.

As shown in Fig. 2c, in MCF-7 cells, a cyclin D1 promoter construct driving luciferase expression was induced by $E_{2}$ but significantly inhibited following DHT coadministration. The overexpression of AR resulted in the complete loss of the transcriptional signal induced by $E_{2}$ when compared with hormone stimulated activity in the absence of exogenous AR. Additionally, in these experimental conditions, a further decrease in $\mathrm{E}_{2}$-dependent cyclin D1 promoter activity was observed following DHT treatment. The androgen-dependent inhibition of $\mathrm{E}_{2}$-activated signalling on cyclin D1 gene promoter was abrogated by the addition of the androgen antagonist OHFl, confirming the involvement of AR.

\section{AIB1 overexpression rescues AR repression of estradiol- induced transcriptional activity of cyclin D1 promoter} The capacity of AR to compromise the transcriptional response dependent on a second receptor such as ER $\alpha$, implies that shared components of the transcriptional

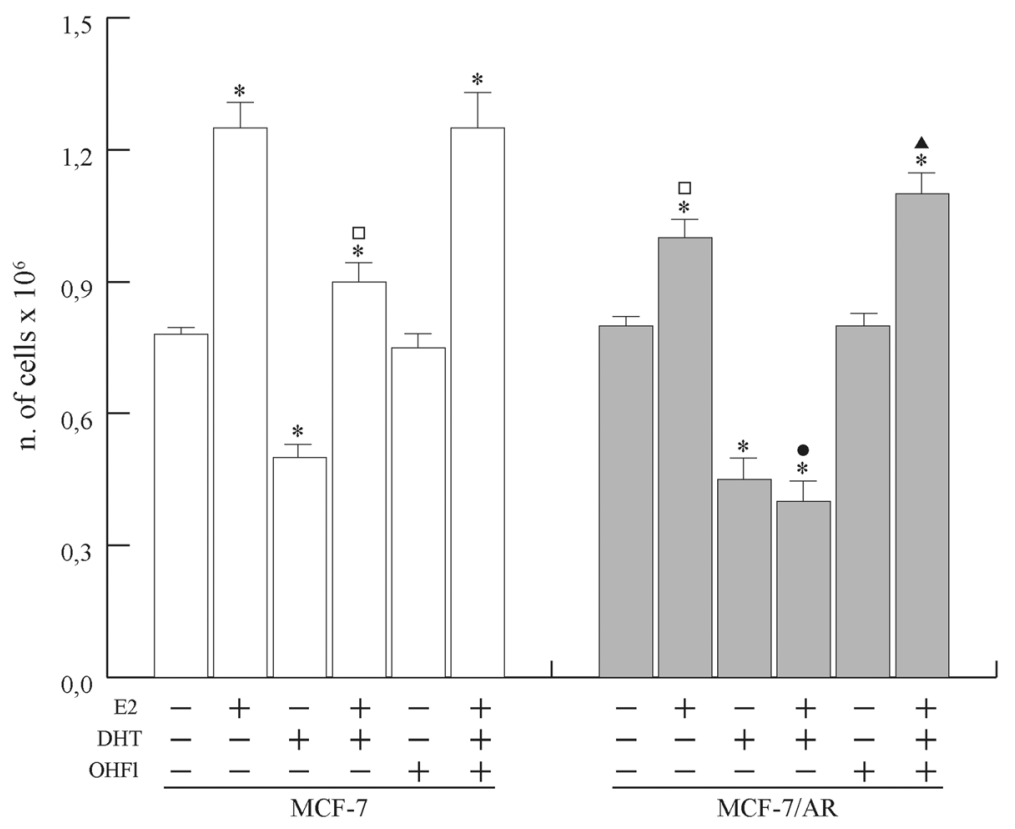

Fig. 1 Over-expressed androgen receptor inhibits $E_{2}$-dependent MCF-7 cells proliferation. MCF-7 cells and and MCF-7 transiently over-expressing AR (MCF-7/AR), were synchronized in PRF and treated with $10^{-7} \mathrm{M} \mathrm{E}_{2}$, and/or $10^{-7} \mathrm{M} \mathrm{DHT}$, and/or $10^{-6} \mathrm{M} \mathrm{OH}$-Fl in steroids depleted PRF-CT for 3 days. Data represent a mean \pm s.d. of three independent experiments, each in duplicate. ${ }^{*} p \leq 0.05$ vs untreated MCF-7 cells; ${ }^{\square} p \leq 0.05$ vs. $E_{2^{-}}$ treated MCF-7 cells; $p \leq 0.05$ vs $E_{2}+$ DHT treated MCF-7 cells; $\boldsymbol{\Delta}^{\bullet} \leq 0.05$ vs $E_{2}+$ DHT treated MCF-7/AR 


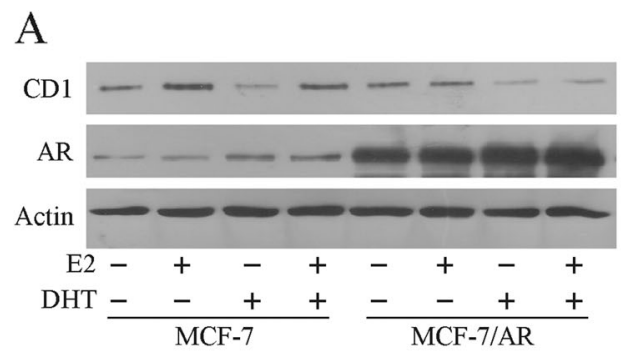

$\mathrm{C}$

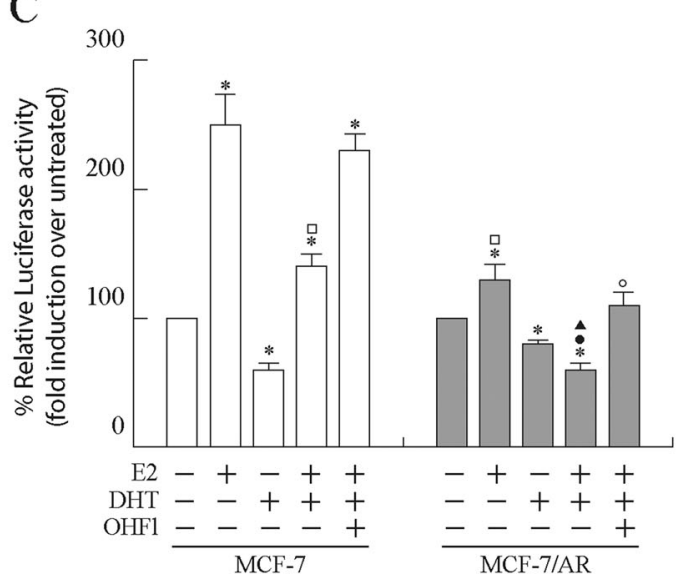

Fig. 2 Estrogen induction of cyclin D1 expression and promoter activity is reduced by over- expression of androgen receptor. a Western blotting analysis of Cyclin D1 (CD1). MCF-7 and MCF-7/AR cells were treated as indicated. Actin was assessed as control of protein loading. b Quantitative Real Time RT-PCR from MCF-7 and MCF-7/AR cells treated as indicated. 18S rRNA was determined as control. Columns are the mean of three independent experiments each in triplicate; bars, SD; ${ }^{*} p \leq 0.05$ vs untreated MCF-7 cells; ${ }^{\square} p \leq 0.05$ vs. $E_{2}$-treated MCF-7 cells; $p \leq 0.05$ vs $E_{2}+$ DHT treated MCF-7 cells. c MCF-7 and MCF-7/AR cells were transiently transfected with pCD1 prom-Luc and treated as indicated. Columns are mean of three independent experiments and expressed as fold induction over untreated, which was assumed to be $100 \%$; bars SD; ${ }^{*} p \leq 0.05$ vs untreated MCF-7 cells; ${ }^{\square} p \leq 0.05$ vs. $E_{2}$-treated MCF-7 cells; ${ }^{\bullet} p \leq 0.05$ vs $E_{2}+$ DHT treated MCF-7 cells; ${ }^{\wedge} p \leq 0.05$ vs. $E_{2}$-treated MCF-7/AR cells; ${ }^{\circ} p \leq 0.05$ vs. $\mathrm{E}_{2}+\mathrm{DHT}$ treated MCF-7/AR cells

machinery are involved [22, 34]. Therefore AR and ER $\alpha$ might use a common pool of co-factors present in limiting cellular concentrations. In this concern, we investigated the role of the steroid receptor coactivator AIB1, that is important in the functional coupling of ER $\alpha$ with the cyclin D1 promoter [28, 35].

To this aim, we first used a AIB1 siRNA approach, to selectively reduce AIB1 expression in MCF-7 cells. The AIB1 siRNA produced a $>80 \%$ reduction in cellular AIB1 protein levels, which were still repressed after $72 \mathrm{~h}$ (Fig. 3a). As shown in Fig. 3b treatment with AIB1 siRNA completely negated the increase in cyclin D1 protein expression induced by estradiol.

Interestingly, this pattern of cyclin D1 expression is similar to the one observed following AR overexpression (Fig. 2b), supporting the hypothesis that AIB1 is essential for $E_{2}$-dependent cyclin D1 expression.

Thus to assess whether AIB1 squelching might be involved in the transcriptional interference of $A R$ on ER $\alpha$ transcriptional signal, we tested whether AIB1 overexpression could rescue AR repression of

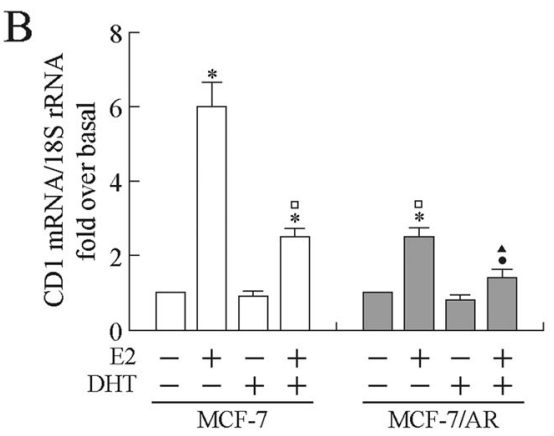




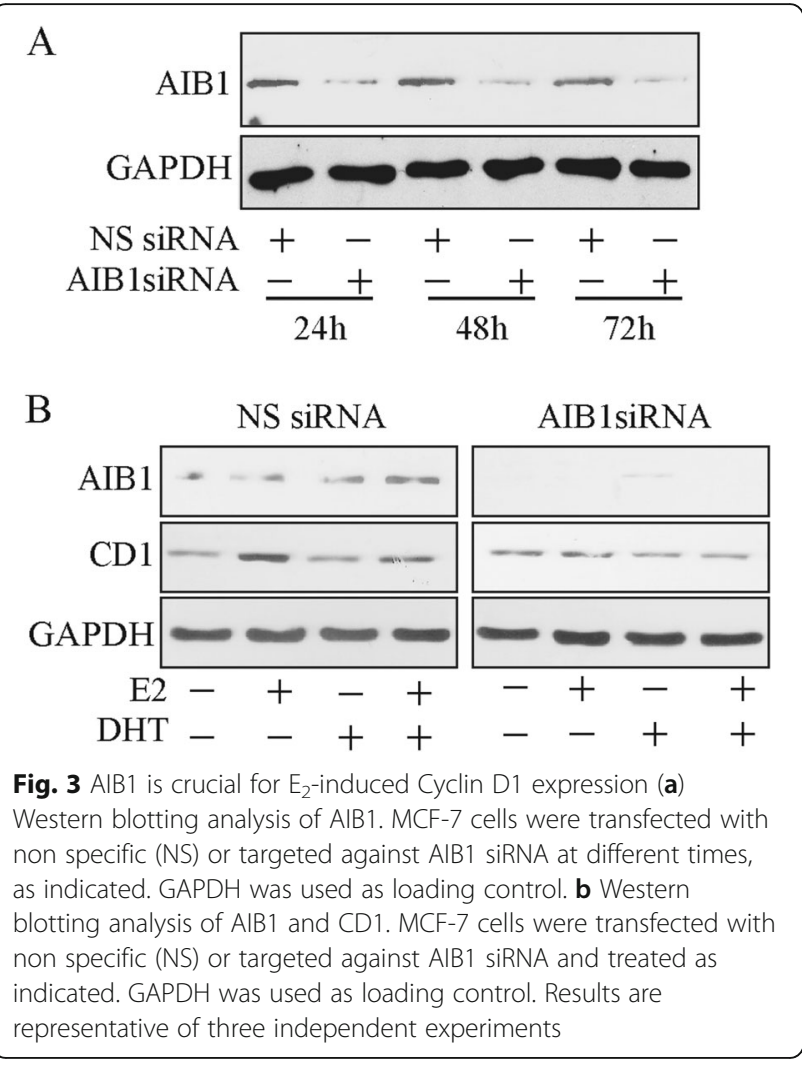

of endogenous ER $\alpha$ and low levels of AR [22], AIB1 coimmunoprecipitates predominantly with ER $\alpha$ in all the examined experimental conditions. On the contrary, following AR overexpression, a prevalent interaction of AIB1 with AR was observed. Specifically, in MCF-7/AR overexpressing cells we found a substantial decrease of AIB1/ER $\alpha$ complex and a concomitant increase of AIB1/ AR interaction, compared to MCF-7 cells. As depicted in Fig. 4c similar experimental conditions reproduced in Hela cells co-expressing ectopic AIB1, ER $\alpha$ and AR, determined analogous results. Indeed, to further prove whether AIB1 is capable to interact with AR and/or ER $\alpha$ in relationship to their intracellular levels, we next performed studies with HeLa cells, a well-known experimental model, which do not express AR or ER $\alpha[38,39]$. In these experiments, coimmunoprecipitation assays were carried out in HeLa cells transiently cotransfected with both $E R \alpha$ and $A R$ in a ratio of $E R \alpha / A R=1: 5$ or at a ratio of $E R \alpha / A R=5: 1$ in the presence of an excess of AIB1. Again, when AR content is higher than ER $\alpha$ (ratio $\mathrm{ER} \alpha / \mathrm{AR}=1: 5)$, AIB1 coimmunoprecipitates mainly with AR while, in the presence of an excess of ER $\alpha$ (ratio ER $\alpha$ $/ A R=5: 1)$, AIB1 primarily coimmunoprecipitates with ER $\alpha$ (Fig. 4c).

It has been reported that AIB1 is required for ER $\alpha$ recruitment onto the estrogen responsive region of the cyclin D1 promoter $[28,40]$. Thus, to highlight the biological implication of $\mathrm{AR} / \mathrm{ER} \alpha$ competition for a shared coactivator such as AIB1 in the regulation of cyclin D1 promoter, we evaluated its recruitment on cyclin D1 promoter by chromatin immunoprecipitation (ChIP) assay in MCF-7 and MCF-7/AR cells (Fig. 4d). Protein-chromatin complexes were immunoprecipitated using specific antibodies against AIB1 or ER $\alpha$. The presence of the specific promoter sequence in the chromatin immunoprecipitates was analyzed by Real-time PCR using specific primers spanning the estrogen-responsive region of the cyclin D1 promoter that contains an AP-1 binding site.

As indicated in Fig. 4d, in MCF-7 cells $E_{2}$-induced recruitment of AIB1 on cyclin D1 proximal promoter was decreased by DHT co-administration. Alongside, in the same experimental conditions, also E2-dependent $\mathrm{ER} \alpha$ binding to the AP-1 containing region was reduced (Fig. 4e). Interestingly and consistent with the above reported data, AR overexpression greatly counteracts either the AIB1 or ER $\alpha$ occupancy of cyclin D1 promoter induced by $\mathrm{E}_{2}$.

\section{Discussion}

Estrogens play a central role in the proliferation and the differentiation of normal mammary epithelial cells as well as the development and progression of breast cancer [41-43]. Indeed, human breast tumorigenesis is promoted by enhanced activity of the estrogen receptor $\alpha$ $(E R \alpha)$ that regulates the transcription of target genes, which in turn direct cellular proliferation [44]. Among these genes, cyclin D1 plays a pivotal role, as highlighted by several lines of evidences. In cyclin D1 knockout mice, mammary gland development is profoundly impaired and more evident during pregnancy when ovarian steroids fail to induce their massive proliferative changes $[45,46]$. Cyclin D1 over-expression has been reported in about $50 \%$ of invasive breast cancer [47] and strongly correlates with ER levels [48-50].

The mechanism by which estrogens regulate cyclin D1 levels in hormone-responsive breast cancer cells is mainly transcriptional. Although no estrogen-responsive element- (ERE) -related sequence has been identified in the cyclin D1 promoter, several potential estrogenresponsive sites have been mapped in the cyclin D1 proximal promoter [24, 40, 51-53].

In the present study we provide a mechanism by which ligand-activated AR, down-regulates estrogendependent MCF-7 human breast cancer cell proliferation by inhibiting the ability of $E_{2} / E R \alpha$ signalling to direct transcription of the cyclin D1 gene promoter. Indeed, in this cell type, co-administration of the non aromatisable androgen DHT, down-regulates the estrogen-dependent induction of cyclin D1 expression at both mRNA and protein levels as well as of its gene promoter activity. 

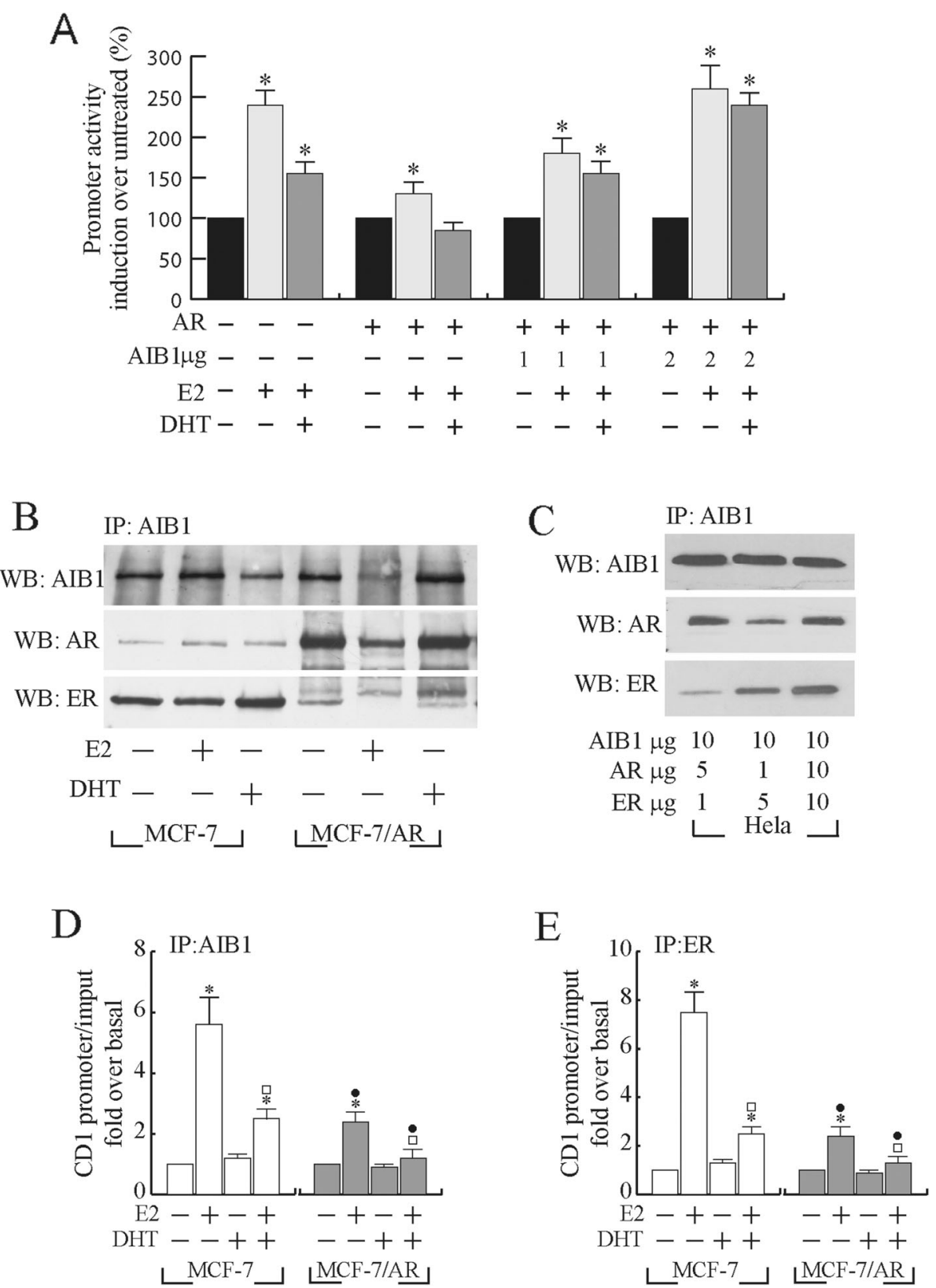

Fig. 4 Over-expressed androgen receptor competes with ERa for AIB1 interaction. a MCF-7 cells, were transiently co-transfected with pCD1promLuc $(0.25 \mu \mathrm{g} /$ well) and /or pcDNA3-AR (AR) and/or increasing amounts (given in $\mu \mathrm{g} /$ well) of full-length AlB1 expression plasmid (AIB1), and treated as indicated. Columns are mean of three independent experiments and expressed as fold induction over untreated, which was assumed to be $100 \%$; bars SD; ${ }^{*} p \leq 0.05$. b Total cell extracts from MCF-7 and MCF-7/AR were immunoprecipitated (IP) with an anti-AIB1 antibody and immunoblotted (WB) to detect AIB1, ER and AR protein levels. Results are representative of three independent experiments. c Total cell extracts from Hela cells transiently cotransfected with different amounts (given in $\mu \mathrm{g} / \mathrm{dish}$ ) of pcDNA3-AR (AR), Hego (ER) or full-length AIB1 expression plasmid as indicated were immunoprecipitated (IP) with an anti-AIB1 antibody and immunoblotted (WB) to detect AIB1, ER and AR protein levels. Results are representative of three independent experiments. $\mathbf{d}$ and $\mathbf{e}$ ChIP-qPCR performed on MCF-7 cells and MCF-7/AR cells using anti-AIB1 (d) or anti- ERa (e) antibodies, as indicated. IgG was used as control. Columns are the mean of three independent experiments. Bars, SD; ${ }^{*} p \leq 0.05$ vs untreated MCF-7 cells; ${ }^{a} p \leq 0.05$ vs. $E_{2}$-treated MCF-7 cells; $\bullet^{p} \leq 0.05$ vs $E_{2}+$ DHT treated MCF-7 cells

It is recognized that ER $\alpha$-mediated transcription is a highly complex process involving a multitude of coregulatory factors and cross-talk among distinct signalling pathways [22, 54]. A number of non-mutually exclusive mechanisms by which the action of steroid receptors might be competitive do exist, including homo- and heterodimers formation, structural analogy of activating ligands, binding to shared DNA response elements or 
sequestration of transcriptional co-regulators present in limiting cellular concentrations $[7,22,55,56]$. Here, we demonstrated that the negative interference of ligandactivated and/or over-expressed $\mathrm{AR}$ on $\mathrm{E}_{2} / \mathrm{ER} \alpha$ dependent transcriptional induction of cyclin D1 involves sharing of the steroid receptor coactivator AIB1, whose abnormal expression is associated with malignancies in estrogen target tissues. Indeed AIB1 was originally identified on the basis of its frequent amplification and over-expression in ovarian and breast cancers $[57,58]$. In addition, AIB1 amplification correlates in primary breast cancers with ER $\alpha$ positivity and tumor size $[59,60]$ and, very recently, it has been proposed that, in ER $\alpha$-positive/HER2-negative invasive breast carcinoma, AIB1 could serve as a new putative prognostic biomarker, with its expression (high AIB1 vs low AIB1) being associated to breast cancer mortality [61]. More, interestingly, AIB1 has an unique role in regulating estrogen-dependent signalling as it is essential for ER $\alpha$ transcriptional activity $[62,63]$. This peculiarity of AIB1 serves as a mechanism by which it influences the growth of hormone-dependent breast cancer as suggested by the observation that depletion of AIB1 affects estrogendependent cell proliferation and survival in ER-positive MCF-7 human breast cancer cells, causing a reduction of MCF-7 xenografts growth in mice [64, 65]. Specifically, in MCF-7 cells, AIB1 represents a rate-limiting factor for estrogen-dependent growth [64] since its cellular levels influence the ability of ER $\alpha$ to interact with the cyclin D1 promoter in an estrogen-dependent manner [28].

Our data evidence that, in MCF-7 cells, exogenously expressed AIB1 reverses the AR repression of $\mathrm{E}_{2}$ dependent transcriptional activity of cyclin D1 promoter suggesting that the transcriptional interference between $A R$ and ER $\alpha$ on cyclin D1 promoter might actually involve competition for limiting amounts of AIB1 in the cell. It has been proposed that coactivators preferentially interact with receptors depending on cell type, ligand and promoter context, which could contribute to the specificity of the physiological response [62, 66]. In our experimental models, the ability of AIB1 to modulate $\mathrm{AR} / \mathrm{ER} \alpha$ interplay is dependent on the steroid receptor cellular content since in MCF-7 cells expressing high levels of endogenous ER $\alpha$ and low levels of AR, AIB1 interacts predominantly with ER $\alpha$. In contrast, AR overexpression induces a dominant interaction of AIB1 with AR. This coactivator squelching between the two steroid receptors impacts on ER $\alpha$-driven transcription of growth regulatory genes. In MCF-7 cells, specific AR ligandactivation, which is associated with an increased AR cellular content $[14,22]$, is able to determine a significant decrease in the estrogen-induced recruitment of AIB1 onto the AP-1 site containing region of the cyclin D1 promoter. Consistent with the notion that AIB1 is fundamental for ER $\alpha$ recruitment within the estrogen- responsive sequence of the cyclin D1 promoter [28], a similar reduction in ER $\alpha$ occupancy of the AP-1 site containing region was also evidenced. Our results well correlate with previous findings showing that loss of AIB1 affects ER $\alpha$-mediated signalling by both directly inhibiting transcriptional initiation and blocking ER $\alpha$ turnover, which may further compromise transcriptional regulation by the receptor [63]. Besides we showed that specific AIB1 knock-down completely abrogated $E_{2}$ effect on cyclin D1 expression.

In conclusion, we demonstrated that the physical squelching of the AR/ER shared coactivator AIB1 may represent at least one of the several potential mechanisms through which AR can negatively modulate $E R \alpha$-mediated signalling pathway and inhibit breast cancer cells proliferation. More precisely, our study emphasizes how coactivator availability may be indeed crucial in determining the transcriptional profile of the cells. Although in a simplified experimental model like ours, findings from the present study reinforce previous observations demonstrating, in ER $\alpha$-positive breast cancer cells, a reciprocal interference between DHT - and estradiol-induced transcriptional program [67], able to shape a unique transcriptional network. We cannot exclude that other receptors could also contribute/influence the interplay between $A R$ and ER $\alpha$ signaling $[68,69]$. Indeed, it is well established that the response of cells to circulating steroid hormones is not the sum of individual hormone action but the result of a functional interaction between different nuclear receptors activating many downstream effector genes and pathways [70, 71]. In this contest it is relevant the finding that even the progesterone receptor (PR) has been demonstrated to be able to modulate ER $\alpha$-DNA binding, directly reprogramming ER $\alpha$-dependent transcriptional programs within breast cancer cells and inhibiting estrogen-mediated growth of ER $\alpha$-positive cell line xenografts [72]. Identification of the potential mechanisms underlying the functional cross-talk between different steroid receptors and the involved specific genes and pathways could provide new hints in hormone receptor actions in breast cancer.

\section{Conclusions}

In summary, our study underlines, once more, the existence in breast cancer cells of a dynamic interplay between $\mathrm{AR}$ and ER $\alpha$ signalling pathways that strictly depends on the hormonal cellular milieu. The biological significance of the AR-induced inhibition of cyclin D1 expression is highlighted by clinical studies in ER $\alpha$ positive breast cancers, showing a better response to adjuvant therapy in cancer patients with cyclin D1 low/ moderate expression than those with high expression of 
cyclin D1 $[73,74]$. In this context, the expression and the functional activity of the AR in breast tissues and tumors, by opposing the estrogen signalling, might play a critical role in regulating cellular proliferation and tissue homeostasis.

Given the high frequency of AR expression in the majority of ER $\alpha$-positive breast tumors, the AR/ER $\alpha$ crosstalk supports the intriguing idea of coupling androgen-based therapy with therapies targeting other important pathways, for the treatment of ER $\alpha$-positive breast cancer patients.

\author{
Abbreviations \\ AIB1: Amplified in Breast Cancer 1; AR: Androgen receptor; DHT: 5-a- \\ dihydrotestosterone; $E_{2}$ : estradiol; ERa: Estrogen Receptor alpha
}

\section{Acknowledgements}

An Abstract of the data described in this study was formerly presented at the "2nd Joint Meeting of Pathology And Laboratory Diagnostics" (De Amicis F., Santoro M., Giordano C., Barone I., Campana A., Morelli C., Bonofiglio D., Lanzino M., Andò S. AR/ER coactivator squelcing contributes to the inhibition of estrogen-dependent cyclin D1 expression in breast cancer. $32^{\circ}$ SIPMeT Meeting, Palermo, Italy, September 19-20, 2014. Published as Supplement to the American Journal Pathology, vol. 184).

\section{Authors' contributions}

FDA and ML conceived and planned the experiments. CC, CM, RB and SM, carried out the experiments and contributed to sample preparation. IC, ML and DS contributed to the interpretation of the results. FDA, ML and DS wrote the manuscript. SA supervised the project. All authors provided critical feedback and helped shape the research, analysis and manuscript. All authors read and approved the final manuscript.

\section{Funding}

This study was supported by Ministero Istruzione Università' e Ricerca -MIUR (ex-60\% 2016) and by Associazione Italiana Ricerca sul Cancro (AIRC) (grant number IG11595; grant number IG15738). The funders had no role in the design of the study; in the collection, analyses, or interpretation of data; in the writing of the manuscript, and in the decision to publish the results.

\section{Availability of data and materials}

Data produced in this study are available from the corresponding author on reasonable request.

\section{Ethics approval and consent to participate}

Not applicable.

\section{Consent for publication}

Not applicable.

\section{Competing interests}

The authors declare that they have no competing interests.

Received: 14 March 2019 Accepted: 15 October 2019

Published online: 04 November 2019

\section{References}

1. Park S, Koo J, Park HS, Kim JH, Choi SY, Lee JH, Park BW, Lee KS. Expression of androgen receptors in primary breast cancer. Ann Oncol. 2010;21(3):488-92.

2. Riva C, Dainese E, Caprara G, Rocca PC, Massarelli G, Tot T, Capella C, Eusebi V. Immunohistochemical study of androgen receptors in breast carcinoma. Evidence of their frequent expression in lobular carcinoma. Virchows Archiv. 2005:447(4):695-700

3. Hickey TE, Robinson JL, Carroll JS, Tilley WD. Minireview: the androgen receptor in breast tissues: growth inhibitor, tumor suppressor, oncogene? Mol Endocrinol. 2012;26(8):1252-67.

4. Dimitrakakis C, Bondy C. Androgens and the breast. Breast Cancer Res. 2009; 11(5):212.
5. McNamara KM, Moore NL, Hickey TE, Sasano H, Tilley WD. Complexities of androgen receptor signalling in breast cancer. Endocr Relat Cancer. 2014; 21(4):T161-81.

6. Berns EM, Dirkzwager-Kiel MJ, Kuenen-Boumeester $\mathrm{V}$, Timmermans $\mathrm{M}$, Verhoog LC, van den Ouweland AM, Meijer-Heijboer H, Klijn JG, van der Kwast TH. Androgen pathway dysregulation in BRCA1-mutated breast tumors. Breast Cancer Res Treat. 2003;79(1):121-7.

7. Peters AA, Buchanan G, Ricciardelli C, Bianco-Miotto T, Centenera MM, Harris $J M$, Jindal S, Segara D, Jia L, Moore NL, et al. Androgen receptor inhibits estrogen receptor-alpha activity and is prognostic in breast cancer. Cancer Res. 2009;69(15):6131-40.

8. Hu R, Dawood S, Holmes MD, Collins LC, Schnitt SJ, Cole K, Marotti JD, Hankinson SE, Colditz GA, Tamimi RM. Androgen receptor expression and breast cancer survival in postmenopausal women. Clinical Cancer Res. 2011; 17(7):1867-74

9. Jiang $H S$, Kuang $X Y$, Sun $W L$, Xu Y, Zheng YZ, Liu YR, Lang GT, Qiao F, Hu X, Shao ZM. Androgen receptor expression predicts different clinical outcomes for breast cancer patients stratified by hormone receptor status. Oncotarget. 2016;7(27):41285-93.

10. Kensler KH, Poole EM, Heng YJ, Collins LC, Glass B, Beck AH, Hazra A, Rosner $\mathrm{BA}$, Eliassen $\mathrm{AH}$, Hankinson $\mathrm{SE}$, et al. Androgen receptor expression and breast Cancer survival: results from the Nurses' health studies. J Natl Cancer Inst. 2018.

11. Eigeliene N, Elo T, Linhala M, Hurme S, Erkkola R, Harkonen P. Androgens inhibit the stimulatory action of 17 beta-estradiol on normal human breast tissue in explant cultures. J Clin Endocrinol Metab. 2012;97(7):E1116-27.

12. Lanzino M, Garofalo C, Morelli C, Le Pera M, Casaburi I, McPhaul MJ, Surmacz E, Ando S, Sisci D. Insulin receptor substrate 1 modulates the transcriptional activity and the stability of androgen receptor in breast cancer cells. Breast Cancer Res Treat. 2009;115(2):297-306.

13. Lanzino M, Sisci D, Morelli C, Garofalo C, Catalano S, Casaburi I, Capparelli C, Giordano C, Giordano F, Maggiolini M, et al. Inhibition of cyclin D1 expression by androgen receptor in breast cancer cells--identification of a novel androgen response element. Nucleic Acids Res. 2010;38(16):5351-65.

14. Ando S, De Amicis F, Rago V, Carpino A, Maggiolini M, Panno ML, Lanzino M. Breast cancer: from estrogen to androgen receptor. Mol Cell Endocrinol. 2002;193(1-2):121-8.

15. Greeve MA, Allan RK, Harvey JM, Bentel JM. Inhibition of MCF-7 breast cancer cell proliferation by 5alpha-dihydrotestosterone; a role for p21(Cip1/ Waf1). J Mol Endocrinol. 2004:32(3):793-810.

16. Lanzino M, Maris P, Sirianni R, Barone I, Casaburi I, Chimento A, Giordano C, Morelli C, Sisci D, Rizza P, et al. DAX-1, as an androgen-target gene, inhibits aromatase expression: a novel mechanism blocking estrogen-dependent breast cancer cell proliferation. Cell Death Dis. 2013:4:e724.

17. Birrell SN, Bentel JM, Hickey TE, Ricciardelli C, Weger MA, Horsfall DJ, Tilley WD. Androgens induce divergent proliferative responses in human breast cancer cell lines. J Steroid Biochem Mol Biol. 1995;52(5):459-67.

18. Doane AS, Danso M, Lal P, Donaton M, Zhang L, Hudis C, Gerald WL. An estrogen receptor-negative breast cancer subset characterized by a hormonally regulated transcriptional program and response to androgen. Oncogene. 2006;25(28):3994-4008.

19. Dimitrakakis C, Zhou J, Wang J, Belanger A, LaBrie F, Cheng C, Powell D, Bondy C. A physiologic role for testosterone in limiting estrogenic stimulation of the breast. Menopause. 2003;10(4):292-8.

20. Murphy LC, Watson P. Steroid receptors in human breast tumorigenesis and breast cancer progression. Biomed Pharmacother. 2002;56(2):65-77.

21. Zhou J, Ng S, Adesanya-Famuiya O, Anderson K, Bondy CA. Testosterone inhibits estrogen-induced mammary epithelial proliferation and suppresses estrogen receptor expression. FASEB J. 2000;14(12):1725-30.

22. Lanzino M, De Amicis F, McPhaul MJ, Marsico S, Panno ML, Ando S. Endogenous coactivator ARA70 interacts with estrogen receptor alpha (ERalpha) and modulates the functional ERalpha/androgen receptor interplay in MCF-7 cells. J Biol Chem. 2005;280(21):20421-30.

23. Velasco-Velazquez MA, Li Z, Casimiro M, Loro E, Homsi N, Pestell RG. Examining the role of cyclin D1 in breast cancer. Future Oncol. 2011;7(6): 753-65.

24. Altucci L, Addeo R, Cicatiello L, Dauvois S, Parker MG, Truss M, Beato M, Sica $V$, Bresciani F, Weisz A. 17beta-estradiol induces cyclin D1 gene transcription, p36D1-p34cdk4 complex activation and p105Rb phosphorylation during mitogenic stimulation of $\mathrm{G}(1)$-arrested human breast cancer cells. Oncogene. 1996;12(11):2315-24. 
25. Brown NE, Jeselsohn R, Bihani T, Hu MG, Foltopoulou P, Kuperwasser C, Hinds PW. Cyclin d1 activity regulates autophagy and senescence in the mammary epithelium. Cancer Res. 2012;72(24):6477-89.

26. Arnold A, Papanikolaou A. Cyclin D1 in breast cancer pathogenesis. J Clin Oncol. 2005;23(18):4215-24.

27. Grillo M, Bott MJ, Khandke N, McGinnis JP, Miranda M, Meyyappan M, Rosfjord EC, Rabindran SK. Validation of cyclin D1/CDK4 as an anticancer drug target in MCF-7 breast cancer cells: effect of regulated overexpression of cyclin D1 and siRNA-mediated inhibition of endogenous cyclin D1 and CDK4 expression. Breast Cancer Res Treat. 2006;95(2):185-94.

28. Planas-Silva MD, Shang Y, Donaher JL, Brown M, Weinberg RA. AlB1 enhances estrogen-dependent induction of cyclin D1 expression. Cancer Res. 2001;61(10):3858-62.

29. De Amicis F, Guido C, Santoro M, Giordano F, Dona A, Rizza P, Pellegrino M, Perrotta I, Bonofiglio D, Sisci D, et al. Ligand activated progesterone receptor $\mathrm{B}$ drives autophagy-senescence transition through a Beclin-1/BCl-2 dependent mechanism in human breast cancer cells. Oncotarget. 2016; 7(36):57955-69.

30. De Amicis F, Guido C, Santoro M, Lanzino M, Panza S, Avena P, Panno ML, Perrotta I, Aquila S, Ando S. A novel functional interplay between progesterone receptor-B and PTEN, via AKT, modulates autophagy in breast cancer cells. J Cell Mol Med. 2014;18(11):2252-65.

31. Kemppainen JA, Lane MV, Sar M, Wilson EM. Androgen receptor phosphorylation, turnover, nuclear transport, and transcriptional activation. Specificity for steroids and antihormones. J Biol Chem. 1992;267(2):968-74.

32. Yeap BB, Krueger RG, Leedman PJ. Differential posttranscriptional regulation of androgen receptor gene expression by androgen in prostate and breast cancer cells. Endocrinology. 1999;140(7):3282-91.

33. Musgrove EA, Lee CS, Buckley MF, Sutherland RL. Cyclin D1 induction in breast cancer cells shortens $\mathrm{G} 1$ and is sufficient for cells arrested in G1 to complete the cell cycle. Proc Natl Acad Sci U S A. 1994;91(17):8022-6.

34. Torchia J, Glass C, Rosenfeld MG. Co-activators and co-repressors in the integration of transcriptional responses. Curr Opin Cell Biol. 1998;10(3):373-83.

35. Furth PA, Cabrera MC, Diaz-Cruz ES, Millman S, Nakles RE. Assessing estrogen signaling aberrations in breast cancer risk using genetically engineered mouse models. Ann N Y Acad Sci. 2011;1229:147-55.

36. Nakles RE, Shiffert MT, Diaz-Cruz ES, Cabrera MC, Alotaiby M, Miermont AM, Riegel AT, Furth PA. Altered AIB1 or AIB1Delta3 expression impacts ERalpha effects on mammary gland stromal and epithelial content. Mol Endocrinol. 2011;25(4):549-63.

37. Zhou XE, Suino-Powell KM, Li J, He Y, Mackeigan JP, Melcher K, Yong EL, Xu HE. Identification of SRC3/AIB1 as a preferred coactivator for hormoneactivated androgen receptor. J Biol Chem. 2010;285(12):9161-71.

38. Kousteni S, Bellido T, Plotkin LI, O'Brien CA, Bodenner DL, Han L, Han K, DiGregorio GB, Katzenellenbogen JA, Katzenellenbogen BS, et al. Nongenotropic, sex-nonspecific signaling through the estrogen or androgen receptors: dissociation from transcriptional activity. Cell. 2001; 104(5):719-30

39. Smith $\mathrm{CL}$, Onate SA, Tsai MJ, O'Malley BW. CREB binding protein acts synergistically with steroid receptor coactivator-1 to enhance steroid receptordependent transcription. Proc Natl Acad Sci U S A. 1996:93(17):8884-8.

40. Sabbah M, Courilleau D, Mester J, Redeuilh G. Estrogen induction of the cyclin D1 promoter: involvement of a CAMP response-like element. Proc Natl Acad Sci U S A. 1999;96(20):11217-22.

41. Feigelson HS, Henderson BE. Estrogens and breast cancer. Carcinogenesis. 1996;17(11):2279-84

42. Korach KS. Insights from the study of animals lacking functional estrogen receptor. Science. 1994;266(5190):1524-7.

43. Frech MS, Halama ED, Tilli MT, Singh B, Gunther EJ, Chodosh LA, Flaws JA, Furth PA. Deregulated estrogen receptor alpha expression in mammary epithelial cells of transgenic mice results in the development of ductal carcinoma in situ. Cancer Res. 2005;65(3):681-5.

44. Tyson JJ, Baumann WT, Chen C, Verdugo A, Tavassoly I, Wang Y, Weiner LM Clarke R. Dynamic modelling of oestrogen signalling and cell fate in breast cancer cells. Nat Rev Cancer. 2011;11(7):523-32.

45. Fantl V, Stamp G, Andrews A, Rosewell I, Dickson C. Mice lacking cyclin D1 are small and show defects in eye and mammary gland development. Genes Dev. 1995;9(19):2364-72.

46. Sicinski P, Donaher JL, Parker SB, Li T, Fazeli A, Gardner H, Haslam SZ, Bronson RT, Elledge SJ, Weinberg RA. Cyclin D1 provides a link between development and oncogenesis in the retina and breast. Cell. 1995;82(4):621-30.
47. Tobin NP, Bergh J. Analysis of Cyclin D1 in breast Cancer: a call to arms. Curr Breast Cancer Rep. 2012;4(3):171-3.

48. Jares P, Rey MJ, Fernandez PL, Campo E, Nadal A, Munoz M, Mallofre C, Muntane J, Nayach I, Estape J, et al. Cyclin D1 and retinoblastoma gene expression in human breast carcinoma: correlation with tumour proliferation and oestrogen receptor status. J Pathol. 1997;182(2):160-6.

49. Hui R, Cornish AL, McClelland RA, Robertson JF, Blamey RW, Musgrove EA, Nicholson RI, Sutherland RL. Cyclin D1 and estrogen receptor messenger RNA levels are positively correlated in primary breast cancer. Clin Cancer Res. 1996:2(6):923-8.

50. Yang C, Trent S, lonescu-Tiba V, Lan L, Shioda T, Sgroi D, Schmidt EV. Identification of cyclin D1- and estrogen-regulated genes contributing to breast carcinogenesis and progression. Cancer Res. 2006;66(24):11649-58.

51. Castro-Rivera E, Samudio I, Safe S. Estrogen regulation of cyclin D1 gene expression in ZR-75 breast cancer cells involves multiple enhancer elements. J Biol Chem. 2001;276(33):30853-61.

52. Liu MM, Albanese C, Anderson CM, Hilty K, Webb P, Uht RM, Price RH Jr, Pestell RG, Kushner PJ. Opposing action of estrogen receptors alpha and beta on cyclin D1 gene expression. J Biol Chem. 2002;277(27):24353-60.

53. Park KJ, Krishnan V, O'Malley BW, Yamamoto Y, Gaynor RB. Formation of an IKKalpha-dependent transcription complex is required for estrogen receptor-mediated gene activation. Mol Cell. 2005;18(1):71-82.

54. Hall JM, Couse JF, Korach KS. The multifaceted mechanisms of estradiol and estrogen receptor signaling. J Biol Chem. 2001;276(40):36869-72.

55. Migliaccio A, Di Domenico M, Castoria G, Nanayakkara M, Lombardi M, de Falco A, Bilancio A, Varricchio L, Ciociola A, Auricchio F. Steroid receptor regulation of epidermal growth factor signaling through Src in breast and prostate cancer cells: steroid antagonist action. Cancer Res. 2005;65(22):10585-93.

56. Carroll JS, Liu XS, Brodsky AS, Li W, Meyer CA, Szary AJ, Eeckhoute J, Shao W, Hestermann EV, Geistlinger TR, et al. Chromosome-wide mapping of estrogen receptor binding reveals long-range regulation requiring the forkhead protein FoxA1. Cell. 2005;122(1):33-43.

57. Anzick SL, Kononen J, Walker RL, Azorsa DO, Tanner MM, Guan XY, Sauter G, Kallioniemi OP, Trent JM, Meltzer PS. AIB1, a steroid receptor coactivator amplified in breast and ovarian cancer. Science. 1997;277(5328):965-8.

58. List HJ, Reiter R, Singh B, Wellstein A, Riegel AT. Expression of the nuclear coactivator AIB1 in normal and malignant breast tissue. Breast Cancer Res Treat. 2001;68(1):21-8.

59. Bautista $S$, Valles $H$, Walker RL, Anzick S, Zeillinger R, Meltzer $P$, Theillet $C$. In breast cancer, amplification of the steroid receptor coactivator gene AIB1 is correlated with estrogen and progesterone receptor positivity. Clin Cancer Res. 1998;4(12):2925-9.

60. Kurebayashi J, Otsuki T, Kunisue H, Tanaka K, Yamamoto S, Sonoo H. Expression levels of estrogen receptor-alpha, estrogen receptor-beta, coactivators, and corepressors in breast cancer. Clin Cancer Res. 2000; 6(2):512-8.

61. Narbe U, Sjostrom M, Forsare C, Bendahl PO, Alkner S, Leeb-Lundberg LMF, Lovgren K, Ryden L, Ingvar C, Ferno M. The estrogen receptor coactivator AIB1 is a new putative prognostic biomarker in ER-positive/HER2-negative invasive lobular carcinoma of the breast. Breast Cancer Res Treat. 2019.

62. Tikkanen MK, Carter DJ, Harris AM, Le HM, Azorsa DO, Meltzer PS, Murdoch FE. Endogenously expressed estrogen receptor and coactivator AIB1 interact in MCF7 human breast cancer cells. Proc Natl Acad Sci U S A. 2000;97(23):12536-40.

63. Shao W, Keeton EK, McDonnell DP, Brown M. Coactivator AIB1 links estrogen receptor transcriptional activity and stability. Proc Natl Acad Sci U S A. 2004;101(32):11599-604.

64. List HJ, Lauritsen KJ, Reiter R, Powers C, Wellstein A, Riegel AT. Ribozyme targeting demonstrates that the nuclear receptor coactivator AIB1 is a ratelimiting factor for estrogen-dependent growth of human MCF-7 breast cancer cells. J Biol Chem. 2001;276(26):23763-8.

65. Karmakar S, Foster EA, Smith CL. Unique roles of p160 coactivators for regulation of breast cancer cell proliferation and estrogen receptor-alpha transcriptional activity. Endocrinology. 2009:150(4):1588-96.

66. van de Wijngaart DJ, Dubbink HJ, van Royen ME, Trapman J, Jenster G. Androgen receptor coregulators: recruitment via the coactivator binding groove. Mol Cell Endocrinol. 2012;352(1-2):57-69.

67. Need EF, Selth LA, Harris TJ, Birrell SN, Tilley WD, Buchanan G. Research resource: interplay between the genomic and transcriptional networks of androgen receptor and estrogen receptor alpha in luminal breast cancer cells. Mol Endocrinol. 2012;26(11):1941-52. 
68. Jozwik KM, Carroll JS. Pioneer factors in hormone-dependent cancers. Nat Rev Cancer. 2012;12(6):381-5.

69. Welboren WJ, van Driel MA, Janssen-Megens EM, van Heeringen SJ, Sweep FC, Span PN, Stunnenberg HG. ChIP-Seq of ERalpha and RNA polymerase II defines genes differentially responding to ligands. EMBO J. 2009;28(10): 1418-28.

70. Cicatiello L, Mutarelli M, Grober OM, Paris O, Ferraro L, Ravo M, Tarallo R, Luo S, Schroth GP, Seifert M, et al. Estrogen receptor alpha controls a gene network in luminal-like breast cancer cells comprising multiple transcription factors and microRNAs. Am J Pathol. 2010;176(5):2113-30.

71. Jia L, Berman BP, Jariwala U, Yan X, Cogan JP, Walters A, Chen T, Buchanan $G$, Frenkel B, Coetzee GA. Genomic androgen receptor-occupied regions with different functions, defined by histone acetylation, coregulators and transcriptional capacity. PLoS One. 2008;3(11):e3645.

72. Mohammed H, Russell IA, Stark R, Rueda OM, Hickey TE, Tarulli GA, Serandour AA, Birrell SN, Bruna A, Saadi A, et al. Progesterone receptor modulates ERalpha action in breast cancer. Nature. 2015;523(7560):313-7.

73. Jirstrom K, Stendahl M, Ryden L, Kronblad A, Bendahl PO, Stal O, Landberg G. Adverse effect of adjuvant tamoxifen in premenopausal breast cancer with cyclin D1 gene amplification. Cancer Res. 2005;65(17):8009-16.

74. Stendahl M, Kronblad A, Ryden L, Emdin S, Bengtsson NO, Landberg G. Cyclin D1 overexpression is a negative predictive factor for tamoxifen response in postmenopausal breast cancer patients. $\mathrm{Br} J$ Cancer. 2004 90(10):1942-8

\section{Publisher's Note}

Springer Nature remains neutral with regard to jurisdictional claims in published maps and institutional affiliations.

Ready to submit your research? Choose BMC and benefit from:

- fast, convenient online submission

- thorough peer review by experienced researchers in your field

- rapid publication on acceptance

- support for research data, including large and complex data types

- gold Open Access which fosters wider collaboration and increased citations

- maximum visibility for your research: over $100 \mathrm{M}$ website views per year

At $\mathrm{BMC}$, research is always in progress.

Learn more biomedcentral.com/submissions 